
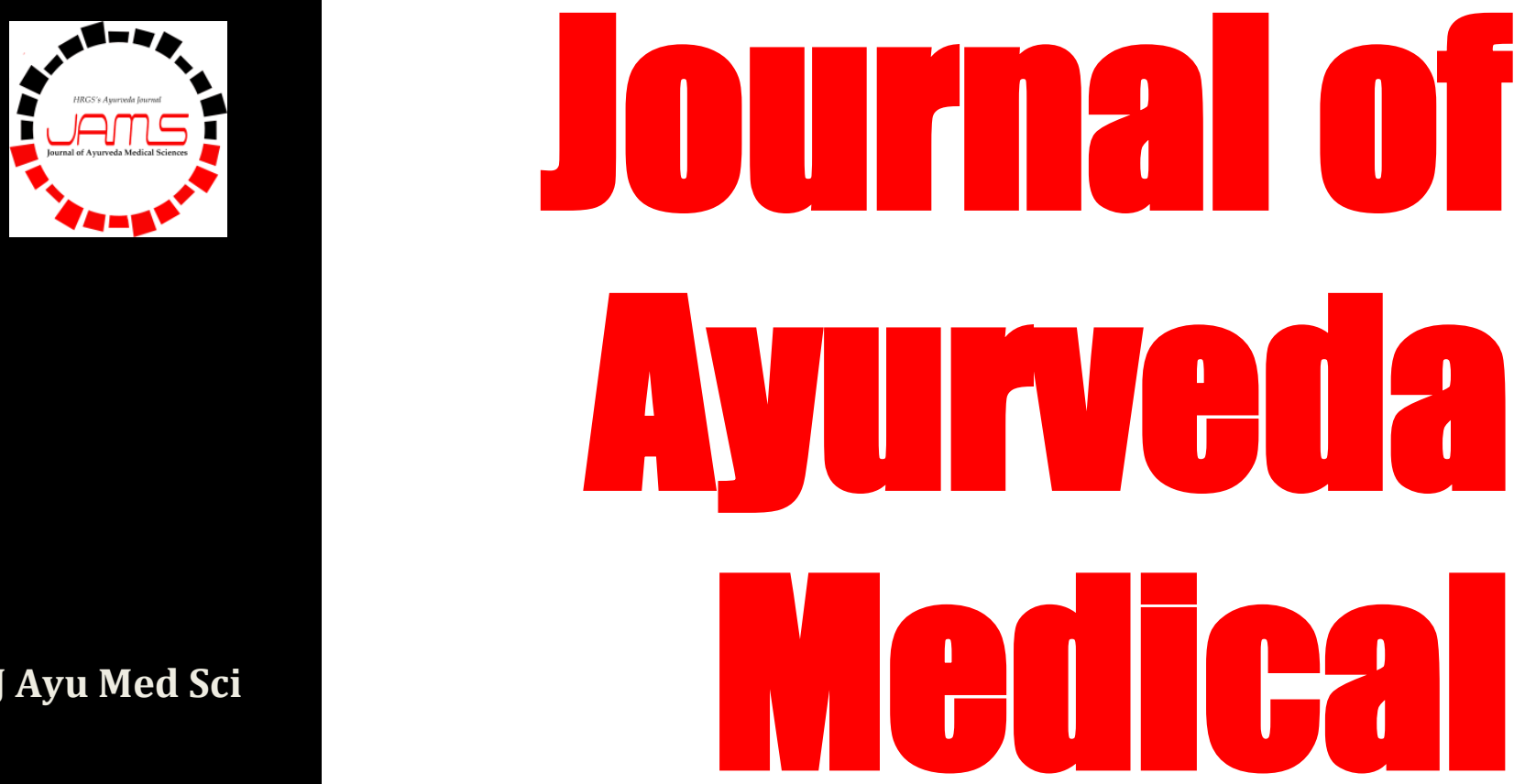

Quarterly Journal for

Rapid Publication

of Researches

in Ayurveda

and Other Traditional

Medicines

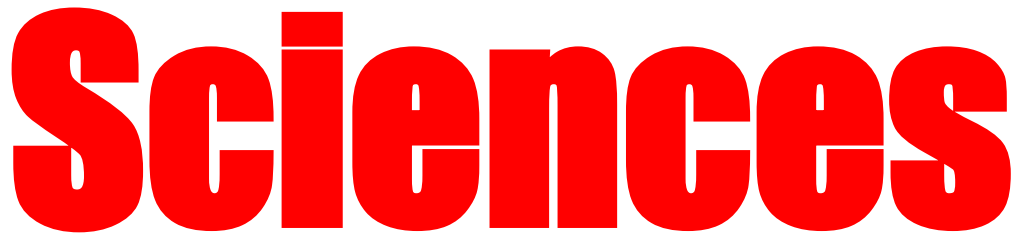

www.jayumedsci.com

ISSN 2456-4990

\title{
Characterization of Pharmacognostical and Preliminary
}

Phytochemical Features of Tubers of Dioscorea oppositifolica L.

Ayurveda opines that the plants which are grown in one's own vicinity should be used for food and medicinal needs. Rare knowledge on folklore plants is passed on from generations to generations traditionally. One such plant is Dioscorea oppositifolia L. (Dioscoreaceae) found frequently in Udupi locally known as Kaadu genasu. The plant is large climber with numerous cylindrical tubers which are consumed as food as it is very nutritive and used as food during famine. On account of these utilities of this less explored plant material, a detailed pharmacognostical study including macro and microscopy HPTLC, nutritional values were conducted. Results of this study can be utilized for identification and purity standards this extra pharmacopoeial drug.

Sagri et al. 


\section{Characterization of Pharmacognostical and Preliminary Phytochemical Features of Tubers of Dioscorea oppositifolica L.}

Ravikrishna Sagri ${ }^{*}$, Shrikanth Padigar, Tantrady Shridhara Bairy, Suchitra Narayan Prabhu'

Department of Dravyaguna, Sri Dharmasthala Manjunatheshwara College of Ayurveda and Hospital, ${ }^{1}$ Department of Pharmacognosy and Phytochemistry, Sri Dharmathala Manjunatheshara Centre for Research in Ayurveda and Allied Sciences, Kuthpady, Udupi 5741 18, India.

\section{ABSTRACT}

Introduction: Ayurveda opines that the plants which are grown in one's own vicinity should be used for food and medicinal needs, though beneficial either as food or as medicine there are many less explored plants. Rare knowledge on folklore plants is passed on from generations to generations traditionally. One such plant is Dioscorea oppositifolia L. (Dioscoreaceae) found frequently in and around Udupi locally known as Kaadu genasu. The plant is large climber with numerous cylindrical tubers which are consumed as food as it is very nutritive and used as food during famine. On account of these utilities of this less explored plant material, a detailed pharmacognostical study including macro and microscopy was conducted. Methods: : Tubers of $D$. oppositifolia L. was subjected to organoleptic, macro microscopic, physicochemical, HPTLC, nutritional values assessment, characterization employing standard methodology mentioned in pharmacopoeia and other herbal analysis protocols. Results: The matured tubers of $D$. oppositifolia $\mathrm{L}$. is on an average $25 \mathrm{~cm}$ in length 3 to $4 \mathrm{~cm}$ in diameter; cylindrically elongated; outer surface is off white with lot of rootlets and cut inner surface is white and mucilaginous. TS of tuber consists of 3 to 5 layers of thinwalled cork cells, followed by cortex formed from thin-walled parenchyma having lot of starch grains; ground tissue consists of parenchyma cells consisting of cells with contents, starch grains and acicular crystals; endodermis layer which is distinct is present following cortex; groups of scattered vascular bindles, comprising of vessels with crown of phloem patches occur towards the inner regions. Preliminary phytochemical study revealed the presence of alkaloids, steroids, carbohydrates and saponins. HPTLC photo documentation showed. No spot under short UV, 4 bands under long UV and 5 bands under white light after derivatisation with vanillin sulphuric acid reagent. Conclusion: Results of this study can be utilized for identification of the drug as well as systematic document on purity standards of this extra pharmacopoeial drug.

KEYWORDS Dioscoreaceae, Folklore, Kaadu genasu, Pharmacopoeia, Standardization

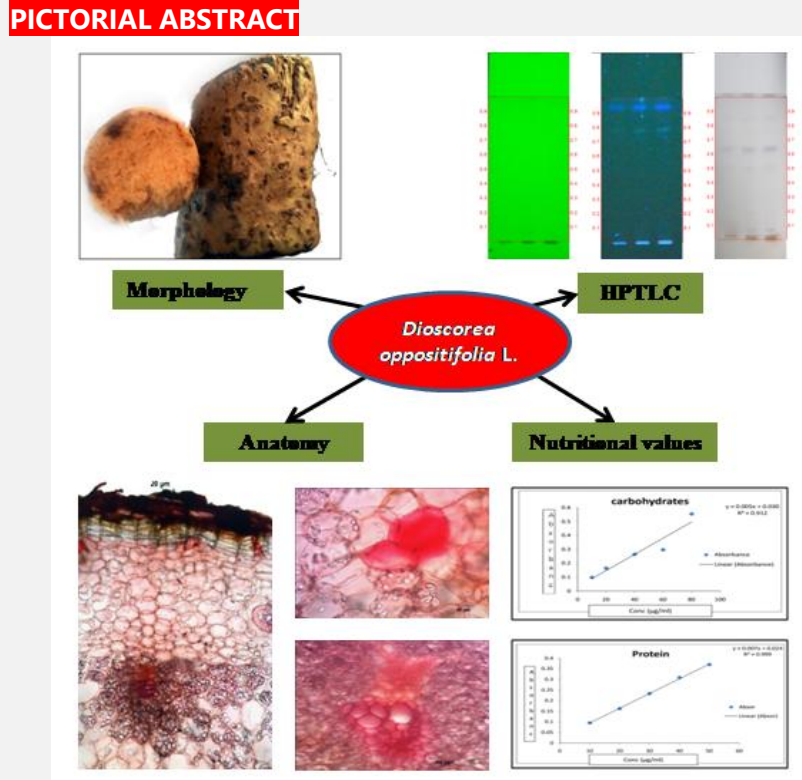

ARTICLE HISTORY Received 25.10.2018 Accepted 31.12.2018

CORRESPONDENCE Dr Ravikrishna S, PhD Scholar, Department of Dravyaguna, Sri Dharmasthala Manjunatheshwara College of Ayurveda and Hospital, Kuthpady, Udupi 574118, India. Email: drrkaithal@gmail.com

CITE THIS RESEARCH AS Sagri R, Padigar S, Bairy TS, Prabhu SN. Characterization of Pharmacognostical and Preliminary Phytochemical Features of Tubers of Dioscorea oppositifolica L. J Ayu Med Sci2018;3(3):413-9.

DOI 10.5530/jams.2018.3.21

\section{INTRODUCTION}

According to Acharya Vagbhata a drug which is grown in the same region in which a person lives, will be ideal for that person. That drug which possesses properties similar to the properties of the land, in which a person is born, is suitable for use $^{[1]}$. Such healthy advises are included as religious customs and since it is not followed and a modern diet regimen are adopted people end up in varied types of disorders. In the name of civilization, commercial propaganda and busy lifestyle the knowledge of the surrounding plants are declining day by day and only few exotic plants are highlighted by mass cultivation and marketing. The folk and ethnic people are well aware about such rare, medicinal, nutritionally rich and seasonally available plants. They use naturally available plants judicially for the need of diet and health. D. oppositifolia L. is one such plant which is a large climber twining to right producing many cylindrical tubers. Leaves up to $12 \times 8.5 \mathrm{~cm}$, opposite and alternate, lanceolate to elliptic-oblong, acuminate or obtuse at apex, acute or rounded at base and glabrous; male spikes fascicled on a long, slender rachis; stamens 6; female flowers distant, in solitary or fascicled spikes; capsules pendulous, broader than long; seeds winged all round. Locally called as Kaadu genasu/ Chaayi gadde the tubers are long and cylindrical, whitish, fleshy, and slimy. They are arranged 
horizontally around the base. According to the native informers the tender parts of the tuber are edible as salad. The tubers are washed and ground along with rice with or without black gram and Idli is prepared and it is also used for preparation of Indian dishes like Palya and Sambar. It is a good tonic, tasty and cools the body. There is a reference in Charaka Samhita Sutrasthana 27 /12 about Amlika kanda for which the commentary says "Amlika kandapradhana kamaroopa prasiddha" for which Dr. Bapalal Vidya considered D. oppositifolia L. as the source plant ${ }^{[2]}$. D. bulbifera L. is considered as source plant for Varahikanda explained in Ayurvedic literatures which is considered as good Aphrodisiac $^{[3]}$. The other source of Dioscorea i.e D.esculanta Burkill also showed the spermatogenesis activity ${ }^{[4]}$. Hence by observing these utilities of the tubers, a pharmacognostical study by performing macro-microscopy and preliminary phytochemical study along with nutritional values assessment has been carried out in the present investigation.

\section{MATERIALS AND METHODS}

\subsection{Collection of sample}

Tubers of D.oppositifolia L.were collected from Hebri, Hiriyadka and Belman region of Udupi district during July and August 2016. The authenticity of plant was confirmed by consulting botanist followed by comparison with flora of Udupi ${ }^{[5]}$.

\subsection{Preservation of sample}

Tubers were air dried and preserved in air tight containers at SDM Centre for Research in Ayurveda and Allied Sciences, Udupi for phytochemical studies. For microscopic examination sample was preserved in fixative solution FAA (Formalin $5 \mathrm{ml}+$ Acetic acid $-5 \mathrm{ml}+70 \%$ Ethyl Ethanol $-90 \mathrm{ml}$ ) for more than $48 \mathrm{~h}$.

\subsection{Macroscopy}

The external features of the test samples were documented using Canon IXUS digital camera. The macroscopic features were compared to local flora for authentication.

\subsection{Microscopy}

Sample was preserved in fixative solution. The fixative used was FAA (Formalin-5ml + Acetic acid-5ml + 70\% Ethyl Ethanol-90ml). The materials were left in FAA for more than 48 hours. The preserved specimens were cut into thin transverse section using a sharp blade and the sections were stained with saffranine. The slides were also stained with iodine in potassium iodide for detection of starch. Transverse sections were photographed using Zeiss AXIO trinocular microscope attached with Zeiss AxioCam camera under bright field light. Magnifications of the figures are indicated by the scale-bars.

\subsection{Physico-chemical analysis}

Powder was tested for pharmacopoeial constants like loss on drying at $105^{\circ} \mathrm{C}$, total ash, acid insoluble ash, Ethanol soluble extractive, water soluble extractive as per standard protocol $^{[6]}$.

\subsection{Preliminary phytochemical analysis}

Tests were done to detect the presence of alkaloids, steroids, carbohydrates, tannin, flavanoids, saponins, triterpenoids, coumarins and phenols in Ethanolic extracts of tuber $^{[7]}$.

\subsection{HPTLC}

One g of D. oppositifolia L. tuber powder was extracted with $10 \mathrm{ml}$ of ethanol. 4,8 and $12 \mu \mathrm{l}$ of the above extract were applied on a pre-coated silica gel F254 on aluminum plates to a band width of $7 \mathrm{~mm}$ using Linomat 5 TLC applicator. The plate was developed in toluene: ethyl acetate (7.0: 3.0). The developed plates were visualized in short UV, long UV and then derivatised with vanillin sulphuric acid (VSA) and scanned under UV 254nm, $366 \mathrm{~nm}$ and $620 \mathrm{~nm}$. $\mathrm{R}_{\mathrm{f}}$, colour of the spots and densitometric scan were recorded $^{[8,9]}$.

\subsection{Nutritional values assessment}

Determination of fat, fibre, $\operatorname{protein}^{[10]}$ and carbohydrate ${ }^{[11]}$ was done using standard procedures.

\section{RESULTS AND DISCUSSION}

\subsection{Macroscopy}

The matured tubers of $D$. oppositifolia L. are on an average $25 \mathrm{~cm}$ in length 3 to $4 \mathrm{~cm}$ in diameter. The outer surface is pale white in color and inner it is white color. They are cylindrically elongated tubers, contains small rootlets in the outer surface. The cut end will be mucilaginous as seen in (Fig 1).

\subsection{Microscopy}

TS of tuber consists of 3 to 5 layers of thin-walled cork cells, followed by cortex formed from thin-walled parenchyma having lot of starch grains; ground tissue consists of parenchyma cells consisting of cells with contents, starch grains and acicular crystals; endodermis layer which is distinct is present following cortex; groups of scattered vascular bindles, comprising of vessels with crown of phloem patches occur towards the inner regions (Fig 2). 


\section{Figure 1. Macroscopy of tuber of Dioscorea oppositifolia L.}

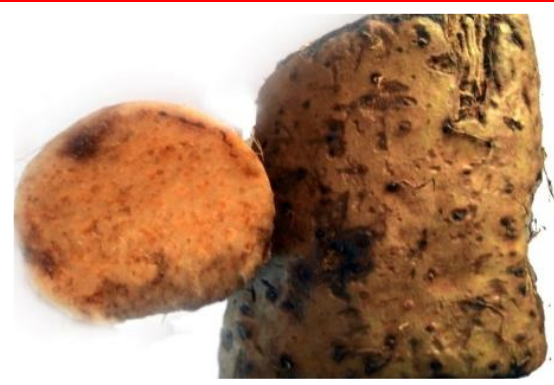

\section{Figure 2. Microscopy of tuber of Dioscorea oppositifolia L.}

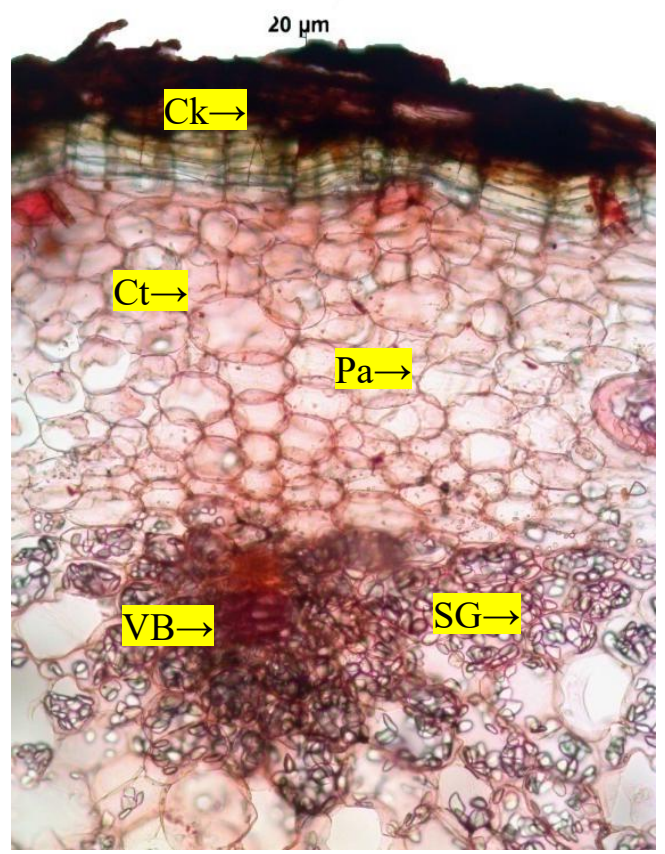

2.1 Cork and cortex enlarged

$\mathrm{Ck}$ - cork; $\mathrm{Ct}$ - cortex; $\mathrm{Pa}$ - parenchyma; $\mathrm{SG}$ - starch grains; $\mathrm{VB}$ - vascular bundle

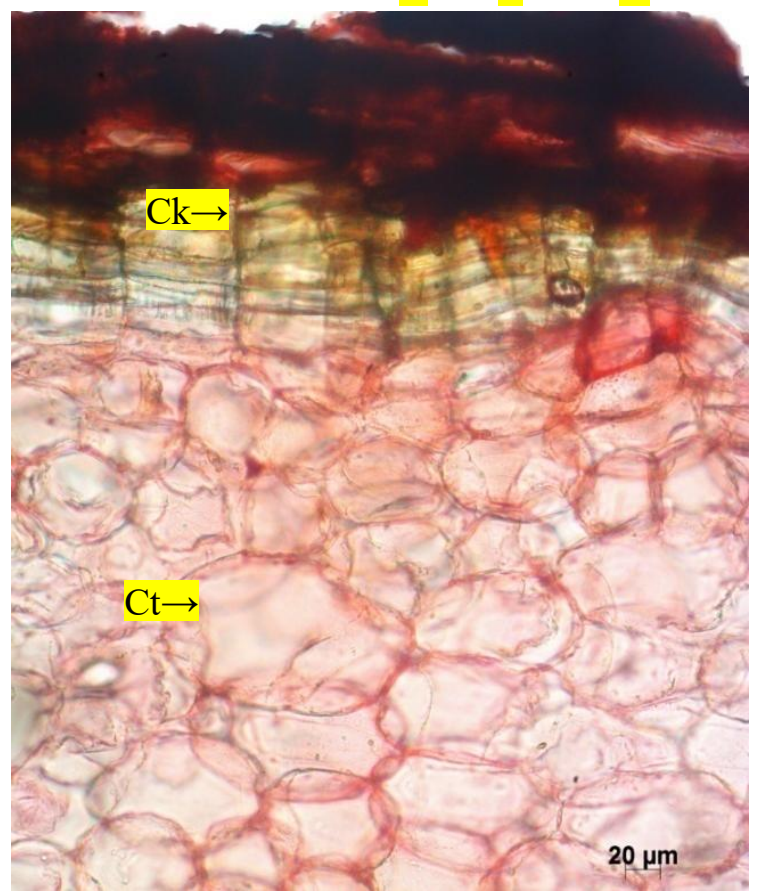

2.3 Cork and cortex

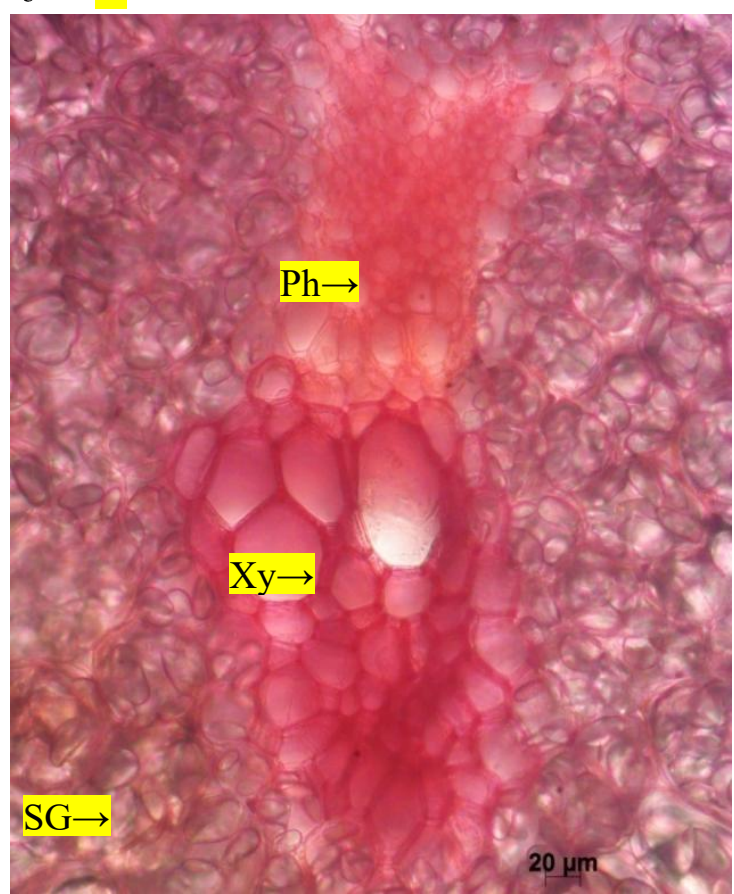

2.4. Vascular bundle 


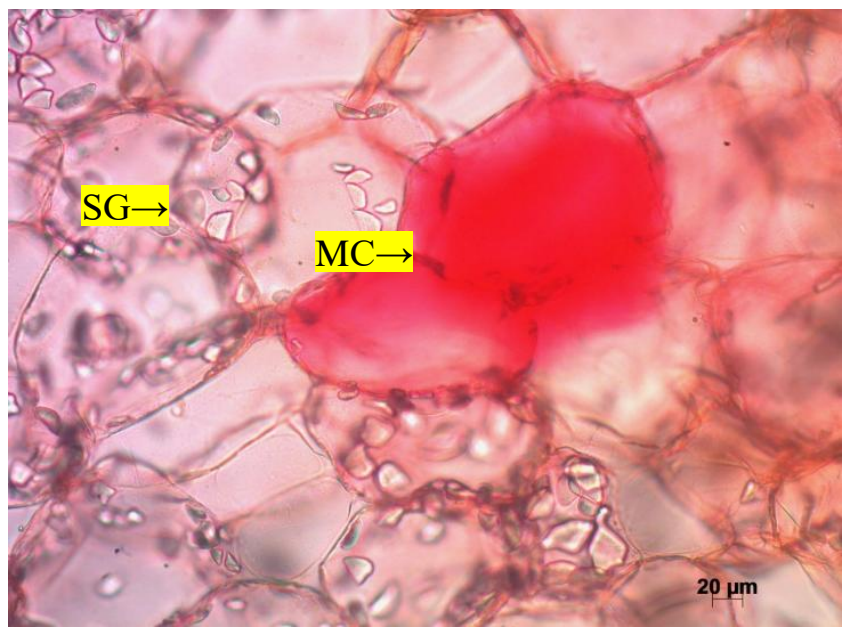

2.5 Mucilage cell

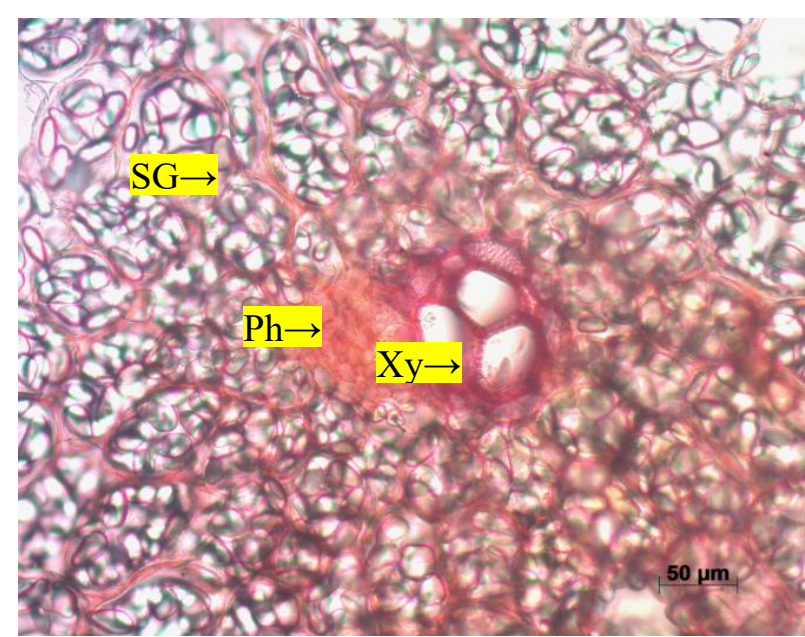

2.6 Vascular bundle

Ck- cork; Ct - cortex; MC - mucilage cell; Ph - phloem; SG - starch grains; Xy - xylem.

\section{Table 1. Results of standardization parameters of tubers of D.oppositifolia L.}

\begin{tabular}{|c|c|}
\hline Parameter & Results $\mathbf{n}=\mathbf{3}$ \%w/w \\
\hline Loss on drying & $12.80 \pm 0.01$ \\
\hline Total Ash & $4.88 \pm 0.12$ \\
\hline Acid Insoluble ash & $1.89 \pm 0.02$ \\
\hline Water soluble ash & $2.09 \pm 0.07$ \\
\hline Ethanol soluble extractive value & $1.17 \pm 0.01$ \\
Water soluble extractive value & $15.59 \pm 0.11$ \\
\hline Fat & 1.24 \\
Fibre & 0.90 \\
\hline Carbohydrate & 36.68 \\
\hline Protein & 9.0 \\
\hline
\end{tabular}

Table 2. Results of preliminary phytochemical screening of tubers of Dioscorea oppositifolia L.

\begin{tabular}{|c|c|c|}
\hline Tests & Colour if positive & Ethanolic extract \\
\hline \multicolumn{3}{|c|}{ Alkaloids } \\
\hline Dragendroff's test & Orange red precipitate & Orange red precipitate \\
\hline Wagners test & Reddish brown precipitate & Reddish brown precipitate \\
\hline Mayers test & Dull white precipitate & Dull white precipitate \\
\hline Hagers test & Yellow precipitate & Yellow precipitate \\
\hline \multicolumn{3}{|c|}{ Steroids } \\
\hline $\begin{array}{l}\text { Liebermann- buchard } \\
\text { test }\end{array}$ & Bluish green colour & Bluish green colour \\
\hline Salkowski test & $\begin{array}{l}\text { Bluish red to cherry red color in chloroform layer and green } \\
\text { fluorescence in acid layer }\end{array}$ & $\begin{array}{l}\text { Bluish red to cherry red color in chloroform layer and green } \\
\text { fluorescence in acid layer }\end{array}$ \\
\hline \multicolumn{3}{|c|}{ Carbohydrate } \\
\hline Molish test & Violet ring & Violet ring \\
\hline Fehlings test & Brick red precipitate & Brick red precipitate \\
\hline Benedicts test & Red precipitate & Red precipitate \\
\hline \multicolumn{3}{|c|}{ Tannin } \\
\hline With $\mathrm{FeCl}_{3}$ & Dark blue or green or brown & Yellow color \\
\hline \multicolumn{3}{|c|}{ Flavanoids } \\
\hline Shinoda's test & Red or pink & Yellow color \\
\hline \multicolumn{3}{|c|}{ Saponins } \\
\hline With $\mathrm{NaHCO}_{3}$ & Stable froth & Stable froth \\
\hline \multicolumn{3}{|c|}{ Triterpenoids } \\
\hline $\begin{array}{c}\text { Tin and thionyl chloride } \\
\text { test }\end{array}$ & Pink & Pink \\
\hline
\end{tabular}




\begin{tabular}{|c|c|c|}
\hline \multicolumn{3}{|c|}{ Coumarins } \\
\hline With $2 \mathrm{~N} \mathrm{NaOH}$ & Yellow & Yellow color \\
\hline \multicolumn{3}{|c|}{ Phenols } \\
\hline $\begin{array}{l}\text { With Ethanolic ferric } \\
\text { chloride }\end{array}$ & Blue to blue black & Yellow color \\
\hline \multicolumn{3}{|c|}{ Carboxylic acid } \\
\hline $\begin{array}{l}\text { With water and } \\
\qquad \mathrm{NaHCO}_{3}\end{array}$ & Brisk effervescence & No brisk effervescence \\
\hline \multicolumn{3}{|c|}{ Amino acid } \\
\hline $\begin{array}{l}\text { With ninhydrine } \\
\text { reagent }\end{array}$ & Purple colour & Yellow color \\
\hline \multicolumn{3}{|c|}{ Resin } \\
\hline With aqueous acetone & Turbidity & No turbidity \\
\hline \multicolumn{3}{|c|}{ Quinone } \\
\hline Conc. sulphuric acid & Pink/purple/red & Light yellow color \\
\hline
\end{tabular}

\begin{tabular}{|c|c|}
\hline Test & Inference \\
\hline Alkaloid & + \\
\hline Steroid & + \\
\hline Carbohydrate & + \\
\hline Tannin & - \\
\hline Flavanoids & - \\
\hline Saponins & + \\
\hline Terpenoid & + \\
\hline Coumarins & + \\
\hline Phenols & - \\
\hline Carboxylic acid & - \\
\hline Aminoacids & - \\
\hline Resin & - \\
\hline Quinone & - \\
\hline
\end{tabular}

\begin{tabular}{|c|c|}
\hline \multicolumn{2}{|c|}{ oppositifolia L. } \\
\hline Long UV & $\begin{array}{l}\text { After Derivatisation (White } \\
\text { light) }\end{array}$ \\
\hline - & 0.07 (L. purple) \\
\hline 0.13 (F. blue) & - \\
\hline - & 0.50 (L. purple) \\
\hline - & 0.63 (D. purple) \\
\hline 0.73 (F. blue) & - \\
\hline - & 0.77 (L. purple) \\
\hline 0.80 (F. green) & - \\
\hline - & 0.86 (L. purple) \\
\hline 0.95 (F. blue) & - \\
\hline
\end{tabular}

Figure 3. HPTLC photo documentation of ethanol extract of tubers of Dioscorea oppositifolia L.

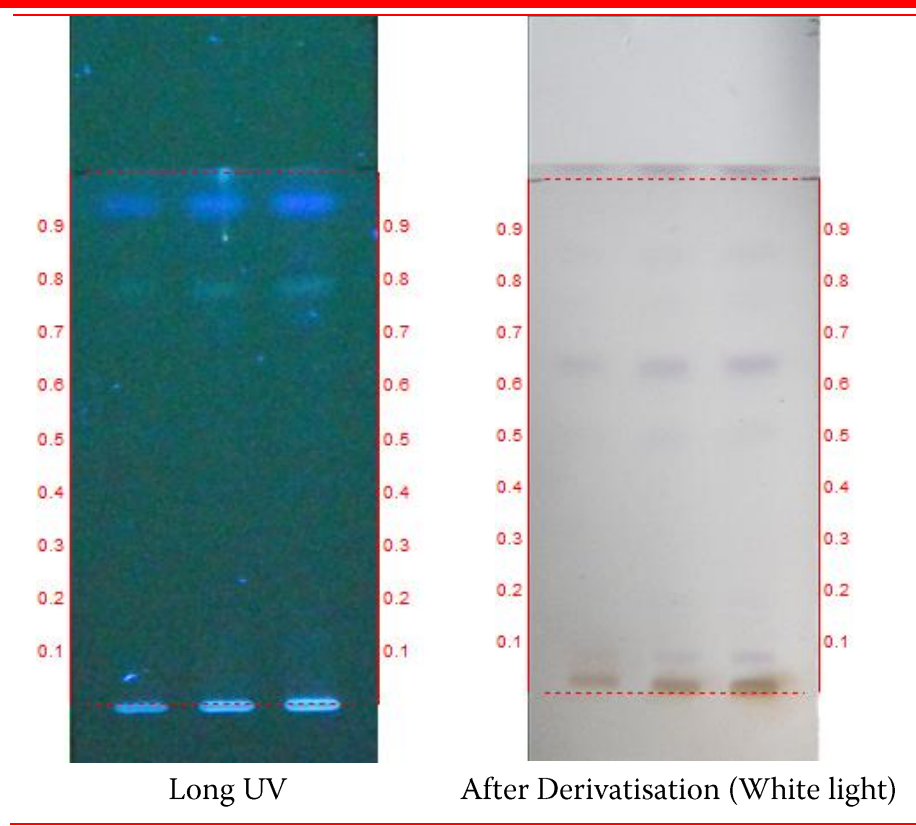

Track 1- $4 \mu \mathrm{l}$; Track $2-8 \mu \mathrm{l}$; Track 3- $12 \mu \mathrm{l}$

Solvent system: Toluene - Ethyl Acetate: Formic acid (7.0: 3.0) 


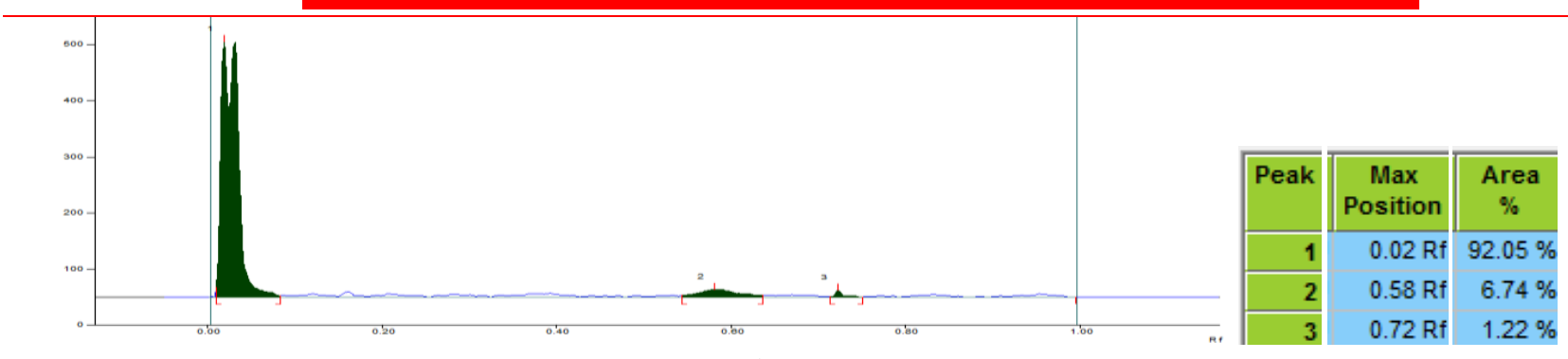

4.1 At $254 \mathrm{~nm}$

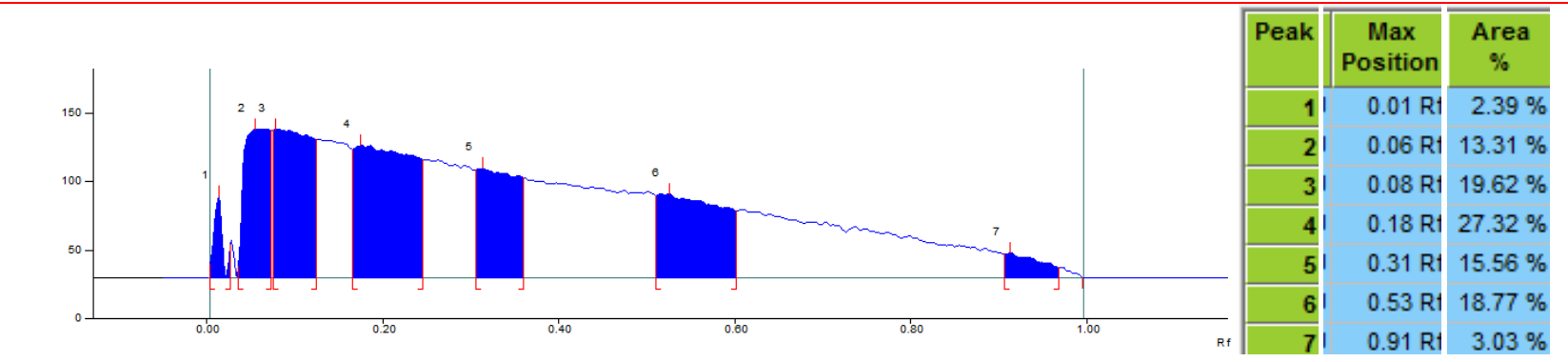

4.2 At $366 \mathrm{~nm}$

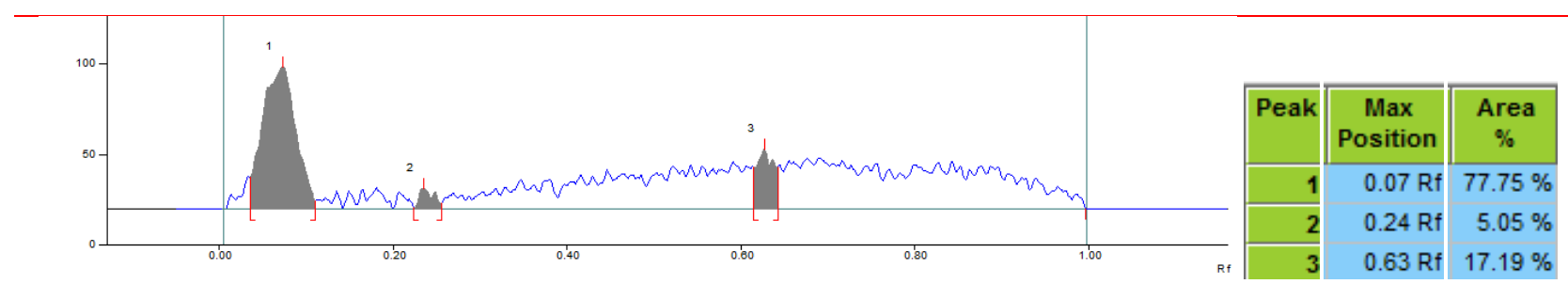

4.3 At $620 \mathrm{~nm}$ (After derivatisation)

The macroscopic features recorded can be used for preliminary identification of the particular plant. In many of studies reported ${ }^{[12]}$ earlier, the macro-microscopic studies have been proved to be effective in establishing the authenticity and detection of adulterants/substitutes for herbal raw drugs. The TS of tuber was evident with the presence of thick walled cork cells, following which there were two to 3 layers of cells which are striated are present on inner side. Cortex was about 12 to 13 layers with cortical parenchyma containing starch grains and cells with beaded wall type of appearance. Vascular bundle with xylem on inner side and phloem outer to it; parenchyma was found to contain numerous starch grains and a few of the parenchyma cells are loaded with mucilage and acicular raphide bundles.

Physico-chemical analysis showed the presence of moisture content of $12.80 \%$ which in turn proves that it has water content which is beneficial as a source of hydration of the body in famine; further, the mucilage content might be responsible for storage of moisture. Total ash was found to be 4.88, acid insoluble ash was found to be $1.89 \%$ which signifies that the area of collection and soil condition is moderately good where silicacious matter and inorganic content is less. Water soluble extractive value was $15.59 \%$ which indicates better absorption in the body and it is nutritional value for the body is advantageous. Ethanol soluble extractive value was found to be $1.17 \%$. The nutritional composition was fat- $1.24 \% \mathrm{w} / \mathrm{w}$, carbohydrate- $36.68 \% \mathrm{w} / \mathrm{w}$, protein- $9.0 \% \mathrm{w} / \mathrm{w}$ and fibre- $0.90 \% \mathrm{w} / \mathrm{w}$ (Table 1 ).

Preliminary phytochemical investigation ethnolic extract of the tuber ascertained the presence of alkaloid, steroid, carbohydrate, which will help us to understand basic chemical nature of the tuber (Table 2).

Upon photo-documentation in short UV no spots were observed and under long UV presence of 4 bands with $R_{\mathrm{f}} 0.13$, 0.73, 0.80, 0.95 (all fuorescnt blue) were present (Fig 3). After derivatiation with VSA and activation of the plate at $105^{\circ} \mathrm{C}$, presence of 5 bands with $\mathrm{R}_{\mathrm{f}} 0.07,0.50,0.77,0.86$ (all light purple) and 0.63 (D. purple) were observed (Table 3).

Densitometric scan at $254 \mathrm{~nm}$ showed the presence of 3 peaks at $\mathrm{R}_{\mathrm{f}} 0.02$ (92.05\%), 0.58 (6.74\%) and $0.72(1.22 \%)$; at $366 \mathrm{~nm}$ 7 peaks at $\mathrm{R}_{\mathrm{f}}$ of $0.01,0.06,0.08,0.18(27.32 \%), 0.31,0.53$ and 0.91 ; and at $620 \mathrm{~nm}$ (post derivatisation with VSA) it showed 3 peaks at $\mathrm{R}_{\mathrm{f}} 0.07$ (77.75\%), 0.24 (5.05\%) and 0.63 (17.19\%) (Fig 4).

\section{CONCLUSION}

Ayurveda Acharyas have opined to make use of the different herbs found in the surrounding area but after thorough examination before incorporating in medicine. The folklore practitioners using such plants for their need have to be properly 
explored and scientifically documented. Present day only popular tuberous vegetables like potatoes, carrot, beetroot etc are popularly used, but there are many other valuable plants which has to be explored to include in our vegetable list. These less explored plants need a systematic and scientific documentation. The current study has evolved standards for one of extra pharmacopoeial drug which can be further analyzed for its pharmacological activities and can be safely used as regular vegetable for nutritional supplement.

ACKNOWLEDGEMENT Authors are grateful to revered President, Dr. D. Veerendra Hegade, SDM Educational Society for constant encouragement. Authors are indebted to Prof. Ravishankar B, Former Director of SDM Centre for Research in Ayurveda and Allied Sciences, Udupi for support.

\section{CONFLICT OF INTEREST Ni}

CONTRIBUTORS Dr. Ravikrishna carried out the whole research work, collection of plant material, pharmacognostical and phytochemical study. Dr Shrikanth contributed to conceptualization of the topic. Dr Shridhara Bairy contributed to intellectual content and manuscript editing. Suchitra Prabhu provided proper guidance and supervision for the study until the finalization of the paper.

\section{REFERENCES}

1. Babu Suresh.S, editor, ( $1^{\text {st }}$ ed.), Ashtanga samgraha of Vagbhata, Sootrasthana; Bheshajaavacharaniyaa: Chapter 23, verse 35 . Varanasi: Choukhambha orientalia, 2004; p.223

2. Vaidya Bapalal, Some controversial drugs in Indian medicine, ed. III Varanasi, 2010 Chaukhambha orientalia, p.274-275.

3. Sitaram Bulusu, commentator, ( $1^{\text {st }}$ ed.), Vol-1, Bhavaprakasha of Bhavamishra, Nigantu bhaaga, Guduchyadi varga, verse 177-179, Varanasi: Choukhambha orientalia, 2006; p.275.

4. Gandhi Tapankumar H. Phyto-pharmacological study on Dioscorea esculanta Burkill. w.s.r to spermatogenesis. M.D (Ayu) thesis, S.D.M. College of Ayurveda, Udupi, Rajiv Gandhi University of Health sciences, Bangalore, India, 2014.

5. Bhat GK. Flora of Udupi: Udupi;Indian Naturalist, 2003; p.645.

6. Quality control methods for medicinal plant materials. Geneva; Organization Mandiale De La Sante; WHO Geneva; 1992;9:22-34.

7. Harborne JB. Method of extraction and isolation in Phytochemical methods. 2nd ed., London: Chapman \& Hall; 1998; p.60-66.

8. Sethi PD. High Performance Thin Layer Chromatography. 1st ed., New Delhi: CBS Publishers and Distributors; 1996; p.1-56.

9. Stahl I. Thin layer Chromatography, a laboratory hand book. Berlin: Springer-Verlag; 1969; p.52-86, 127-8.

10. Raghuramulu N, Madhava NK, Kalyanasundaram S. A manual of Laboratory techniques. Hyderabad: National Institute of Nutrition, 2003; p.57- 63.

11. Krishnaveni S, Theymoli Balasubramanian, Sadasivam S. Food Chem 1984;15:229.

12. Sunil Kumar KN. Macro- and microscopic examination of leaves of Cinnamomum malabatrum (Burm. f.) Blume sold as Tamalapatra. AYU 2013;34(2):193-9. 